\title{
JoséAlaina Franch
}

\section{In memoriam}

BEATRIZ DE LA FUENTE

Instituto de Investigaciones Estéticas, unAM

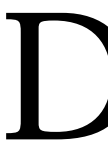

E ENTRE VARIos investigadores españoles dedicados a los temas americanistas, uno de los más destacados fue, sin duda alguna, José Alcina Franch. Levantino de origen, nació en Valencia un no muy lejano 1922. Sus estudios pronto se enfocaron en la arqueología, desde la que optó por acercarse al conocimiento de las antiguas culturas de América al ser estudiante en su ciudad natal, en Sevilla y M adrid. Llevó a cabo sus principales búsquedas intelectuales en Ecuador, Guatemala, M éxico y Perú, países a los que amó entrañablemente y a los que dedicó la mayor parte de sus observaciones desde una perspectiva coherente y global.

El doctor Alcina Franch siempre tocó temas apasionantes y polémicos, no sólo para los historiadores, sino también para arqueólogos, etnólogos y etnohistoriadores. Le interesaba aclarar los desarrollos culturales autóctonos de América, desde C anadá hasta la Tierra del Fuego, y sus posibles contactos a lo largo del tiempo en los diversos territorios del continente.

Apoyado en métodos científicos y teorías diversas, propios de las humanidades y ciencias sociales, Alcina combinó planteamientos rigurosos que le Ilevaron a proponer respuestas viables para los numerosos temas que lo motivaron en sus estudios. Tuvo la capacidad de acercarse críticamente a dichos métodos y sacar de ellos el máximo partido para aplicarlos a la demostración de sus hipótesis, si bien se preocupó de igual modo por dejar las puertas abiertas para nuevas reflexiones y caminos de interpretación. En cada ocasión que se enfrentó a los temas americanistas, lo hizo bajo rigurosa crítica documental y teórica, y llevó de la mano al lector por diferentes senderos del conocimiento sobre la América indígena.

Con extraordinaria capacidad de síntesis logró dirigirse tanto al público especializado como al lego, al mismo tiempo. Su extensa producción e inquietudes intelectuales se reflejan en gran cantidad de trabajos, que entre libros y artículos asciende a casi 450 , y de los cuales todavía hay varios que permanecen inéditos. Entre sus principales obras cabe señalar: Fuentes indíge 
nas de M éxico. Ensayo de sistematización bibliográfica (1956), Floresta literaria de América indígena (1957), M anual de arqueología americana (1965), Origen transatlántico de la cultura indígena de América (1969), En torno a la antropología cultural (1975), L'Art précolombien (1978) y Arte y antropología (1982). Asimismo, se interesó en Los orígenes de América, la Arqueología antropológica y Los aztecas. D e igual manera, se enfrascó en temas teóricos, según se aprecia en obras como Arqueól ogos o anticuarios y Antropólogos y disidentes, en los que pone de relieve las ambigüedades, virtudes y defectos del quehacer arqueológico, antropológico e histórico.

Cabe puntualizar que una de sus obras, Arte y antropología, es resultado de ciertas inquietudes teóricas y puntuales que Alcina percibió tanto en sus investigaciones como en sus labores docentes. Le preocupaba que las ciencias sociales y humanidades hubieran seguido caminos divergentes, a veces paralelos, sin que llegaran a tocarse, a pesar de tener un tema central de estudio común: el ser humano. En ese libro puede encontrarse un resumen crítico y reflexivo de cómo los estudiosos se han enfrentado al pasado americano, pero desde los reducidos ámbitos de la especialidad académica, de suerte que puso en tela de juicio teorías, acercamientos e interpretaciones, y los contempló con base en la antropología misma, en cuanto rama de la filosofía y en sus relaciones con la historia, la historia del arte y otras ciencias afines. La validez de los conceptos y las propuestas de Alcina, a casi 20 años de distancia, se comprueba gracias a que su objetivo es demostrar que las civilizaciones diferentes de 0 ccidente y 0 riente (es decir, las de América precolombina) son sólo eso: diferentes, sin mediar juicios discriminatorios. ${ }^{\mathrm{I}}$

Alcina Franch colaboró también con prestigiosas revistas dedicadas a los estudios americanistas, donde dio a conocer ensayos, datos novedosos, nue vas interpretaciones y reflexiones de índole teórica. Así, cabe citar a Runa, de Argentina; Estudios de Cultura N áhuatl y Anales de Antropología, de M éxico; Anuario de Estudios Americanos, de Sevilla; Estudios N ovohispanos, de Valladolid, y Anuario del Instituto de Antropología e H istoria, de Venezuela.

Las tareas del doctor Alcina no cesaron ahí. Parte de su tiempo lo invirtió en impartir cursos universitarios y dictar conferencias (tanto en España como en el resto de Europa y en América) por más de 40 años, tocantes a los

I. En el Seminario de Investigación y Tesis "Arte prehispánico", de los posgrados en H istoria del Arte y de Estudios M esoamericanos de la Facultad de Filosofía y Letras de la unAm, se ha discutido de modo fructífero esta obra. 
principales temas de su interés: como queda dicho, la etnohistoria y la arqueología americanas.

Tales actividades lo llevaron a ocupar algunos puestos administrativos, en los que descolló su espíritu práctico y crítico. Así, fue director del Seminario de Antropología Americana en la Universidad de Sevilla (de 1959 a 1967), subdirector (1967-1982) y director (198I-1986) del Departamento de Antropología y Etnología de América en la U niversidad Complutense de M adrid, y presidente de la Asociación Guerra y Exilio de M adrid (1998-1999).

Por otra parte, la variada obra del doctor Alcina lo hizo acreedor a diversas preseas y reconocimientos, entre los cuales pueden señalarse la $0 \mathrm{rden}$ al M érito por Servicios Distinguidos de la República del Perú (i968), la Encomienda del M érito Civil de España (1977), las respectivas Ó rdenes del M érito Cultural de la República Popular de Polonia (1980) y de la República del Ecuador (1988) y el "Águila Azteca" del Gobierno de los Estados Unidos M exicanos (1997). En 1997 la Universidad de Londres le dedicó, a manera de homenaje, el simposio "Archaeology and Ethnohistory of the Americas".

Todo lo dicho no es más que una pequeña parte de las muchas tareas que José Alcina Franch llevó a buen término a lo largo de su vida; las obras escritas que nos legó nos pueden acercar un poco a tan fecundo intelectual. Pero todo principio tiene un fin: los estudios americanistas y quienes le conocimos (en persona o por sus libros) nos hemos visto privados de su presencia, pues J osé Alcina Franch murió el 28 de octubre de 200 . \$ 